\title{
Unwitting soldiers: the working life of Matron Hiscocks at the Cootamundra Girls Home
}

\author{
Anna Cole
}

\section{Preface}

Some months ago, I sat watching the television news in London as four young Australian surfers from Perth, the place I grew up, described their experiences of surviving, and helping others survive, the 12 October 2002 bombing of a nightclub in Bali. They reminded me, with a jolt of tender recognition, of my younger brother. Wide laconic accents, faces taut from emotion held in check, inarticulate but palpable love and friendship. I watched, and I thought how much their age and the ordinary things they were saying about their extraordinary acts of bravery resonated with young men from other eras and other wars - these young men on the television, unwitting soldiers in a war that has no boundaries. I continued to watch, with growing discomfort, as the Australian Prime Minister, John Howard, came on the television after them and said the bombing ought not to change Australians from the 'happy, freedom-loving people' they are. While I relished, with the nostalgia of an Australian overseas, this depiction of my country-people, I was reminded of the stultifying hypocrisy that currently pervades much of Australian political life. Howard presented a naïve national picture of a cheerful band of battlers, a picture that, ironically, continues to exclude the first Australian people who battled against enormous odds to maintain families, communities, and spirit under the pressures of colonialism and systematic government policies to disperse and assimilate.

I, like everyone, was shocked and hurt for my fellow Australians and for the 40 Balinese and the Japanese and Turkish tourists who died in the attack. But equally, I was galvanised to argue that while bombs and the lives they destroy have an undeniable urgency, the furor around them can blind us to the many, less sensationalist ways that lives have been, and continue to be, irrevocably changed and in some cases destroyed. This article, in part, urges us to remember that while fresh grieving began in Australia after the bomb in Bali, and a barrage of new wounds have since been opened in the world, old wounds and deep grieving for other matters still remain to be addressed compassionately and responsibly within Australia. Perhaps in some ways it is easier to be rightly shocked and angry at overseas events than it is to continue to engage with the nuances and complexities of much longer-standing, unresolved and deeply painful domestic issues. 


\section{Introduction}

That is how I preface my discussion of an aspect of the work of the Aborigines Welfare Board in NSW from 1939-1969. My focus here is the Cootamundra Girls Home, officially called the Cootamundra Training Home for Aboriginal Girls, which was set up by the Aborigines Protection Board in 1911 in the Cootamundra town's old hospital, $380 \mathrm{~km}$ south-west of Sydney. It was established as a training institution for Aboriginal girls too young to be 'apprenticed' in domestic service. In 1915, as a result of an amendment to the Aborigines Protection Act, the Protection Board - precursor to the Aborigines Welfare Board - was granted the power of acting in loco parentis over all children defined as Aboriginal in NSW. In 1918 the Board was granted further powers to remove all children under 18 years from its reserves. The Home, which ran from 1911 to the late 1960s, acted as a place to hold and train young Aboriginal girls before they turned 14 and could be sent as domestic servants to middle-class homes across the state. Hundreds of girls passed through the Cootamundra Home, and it is remembered by many in the Bringing them home report published by the Human Rights and Equal Opportunities Commission. ${ }^{1}$

I reconstruct here something of the working life of the longest serving matron at the Home, Ella Hiscocks, based on recordings she made with historian Peter Read in $1980{ }^{2}$ on the evidence she gave before a Parliamentary Inquiry in 1966, and on interview material and correspondence with ex-'inmates' (as the Board called the Aboriginal girls and boys) of the home. ${ }^{3}$ Hiscocks, as a functionary of the Board, played her own part in a long-standing and systematic government attempt to break down and assimilate Aboriginal children into white society, a strategy in a wider battle against Aboriginal culture and identity. Yet her own ambivalent and often unhappy memories of her work with the Aborigines Welfare Board are in tension with the historical part she played in implementing a violently racist policy. As her conflicted memories reveal, she was herself something of an unwitting participant of this other war without boundaries that took place on Australian soil and is, to this day, yet to be fully recognised by the government which inherited its legacy. In some part, reconstructing the working life of people such as Ella Hiscocks may assist our understanding of the ideology and circumstances under which ordinary people come to work for, and rationalise, extraordinarily brutal ends.

\section{Working for the Board}

The welfare caused us so much loss and pain. When can we start our grieving? How long are we going to have to grieve? And sometimes I think about how they don't want to spend any money to put things right - but how much did they spend taking the kids away? How much did it cost them? How many of them got jobs and supported their families by taking ours away? ${ }^{4}$

1. Report of the National Inquiry into the Separation of Aboriginal and Torres Strait Islander Children from their Families 1997.

2. Thanks to Peter Read for telling me of this interview, conducted in 1980 with Ella Hiscocks. Lodged at Australian Institute of Aboriginal and Torres Strait Islander Studies (AIATSIS), Listening Room, Canberra [hereafter Read 1980].

3. Some of the interviewees requested anonymity which is reflected in this article. 
Ella Hiscocks recalled that, on visiting the Cootamundra Home for Aboriginal Girls in the early 1940s, 'I could have known it by the smell of $\mathrm{it}^{\prime}$. 5 She had been to the Girls Home, in the old hospital on the edge of town, once before, escorting a young Aboriginal girl there, and had not been impressed. But when offered the position in 1945 of Matron at the Home for three months by the Chairman of the Aborigines Welfare Board, Mr Lipscombe, she took the position reluctantly. ${ }^{6}$ She was at the time under threat of a transfer 'way outback' by the Department of Education for which she worked, and was recently widowed and without recourse to her husband's income or to her former role as the wife of a station manager. A little over 20 years later Hiscocks retired, a story in the Cootamundra Herald noting that she had become the Home's longest-serving matron. ${ }^{7}$

In the decades that followed World War II, white women such as Hiscocks were increasingly employed as Matrons at the Aborigines Welfare Board's children's institutions around the state of NSW and on Aboriginal stations, as 'lady' welfare officers, as teachers and nurses, and, later, as witnesses and government representatives at a Parliamentary Inquiry in the late 1960s which contributed to the abolition of the Board. Assumptions about white women's 'special responsibility' for socialising Aboriginal women and children, for educating about cleanliness and hygiene, and for 'regulating' their sexuality, interacted closely with post-war racial policy and contributed to women's central and largely forgotten role in the administrative and symbolic world of the NSW Aborigines Welfare Board. As in other colonial contexts, the figure of the white woman in NSW was mobilised in both a real and a symbolic way by the administration to facilitate both so-called racial distinctions and their own efforts to modernise bureaucratic control. ${ }^{8}$

Other than the stories of missionary women, for the most part the story of women's work in the colonial administration has been 'shunted to the sidings of history', to borrow a phrase from Anne McClintock. ${ }^{9}$ The working histories of women employed by the Welfare Board show something of the pressures on these women as they negotiated questions of 'race', 'gender' and 'class' in their daily work. Under the bureaucracy of the Aborigines Welfare Board, the management and control of Aboriginal girls and women, specifically the control and surveillance of their domestic arrangements, was an integral part of the 'new standardised practices' of administration that they sought to enact. ${ }^{10}$ The increasing standardisation of women's employment by the Board was endorsed by the administration at a time when a cheap but expanded staff was needed to enact the increased attempts at surveillance stipulated in the Public Service Board report of 1939 that had led to the reformation of the old Aborigines Protection Board. Thus assumptions about the role that white women could play in 'training' for assimilation by monitoring the domestic sphere of Aborigi-

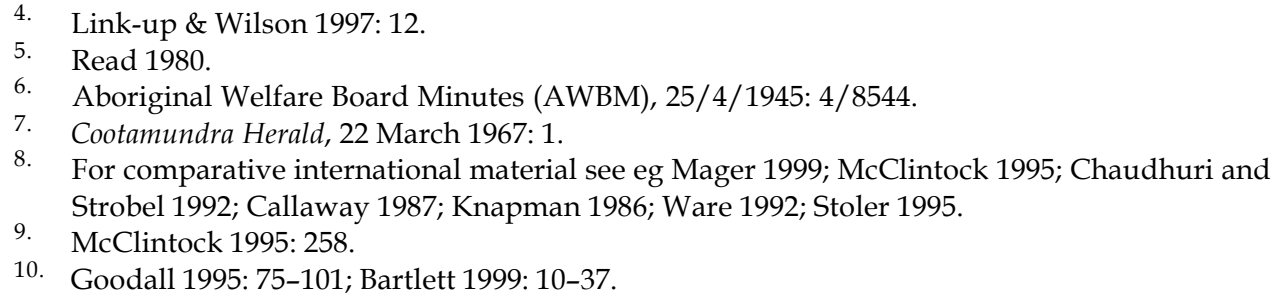


nal lives interacted with an administrative stress on increased surveillance at a time of budgetary cut-backs.

These working women did not, so far as I know, leave collections of letters or journals for historians, as many of their financially independent, middle-class reformist contemporaries did. Instead their days were filled with attempts to 'fight dirt', order domestic environments, 'train' and educate Aboriginal women and children, and in some instances openly criticise the Board's authority. These women's historical traces reveal the different ways ideas about the mission of white femininity intersected with racial administration and the government's efforts to order the domestic worlds of Aboriginal families and communities. ${ }^{11}$

\section{Matron-in-charge}

The job of Matron-in-charge at the Board's Cootamundra Girls Home was one of the significant roles played by a non-Aboriginal women working for the administration. At the end of her career Ella Hiscocks was awarded a Member of the British Empire (MBE) in recognition of her 'work among Aboriginal children'. ${ }^{12}$ Ex-inmates of the Cootamundra Girls' Home remember her work among Aboriginal children a little differently. ${ }^{13}$ Many have mixed memories of Hiscocks, who acted partly as a 'surrogate mother' to hundreds of Aboriginal girls removed from their parents. During her time as Matron of the Cootamundra Home, Ella Hiscocks developed a substitute mother/daughter relationship with one Aboriginal ward in particular, a girl who had been removed from her family and placed in the home when only a few months old. ${ }^{14}$ A significant memory retained by the Aboriginal girl, now a grown woman, is that from about the age of three, before she went to bed each night, the Matron would sit with her and make her pull her nose, 'stroke my nose down the side saying it would make it straight'. ${ }^{15}$

This intimate example is a clue to the ways the rationale that led to the establishment of Homes such as Cootamundra infused the daily actions and interactions of the Board's employees. Individuals working for the administration may have believed themselves to be 'humane' in their relationships to Aboriginal wards, yet in their day to day work, and in their attitudes towards Aboriginality, they contributed to a daily undermining of the self-perception and identity of the children and young adults in their care. More overtly, memories of Hiscocks' humanity and devotion to the girls at the Home are matched with accounts of emotional abuse and the unremitting repression and deprivation experienced under her strict rule. ${ }^{16}$ One woman told how, as an adult, she had finally 'forgiven Matron' who had 'held her spirit captive all her adult life' ${ }^{17}$ She recalls visiting her in a nursing home in Cootamundra in 1998, where Ella

11. This article is drawn from a longer chapter in Cole 2000 that draws on the recorded memories of Ella Hiscocks, Aboriginal Welfare Board Station Reports and Returns from around NSW, and the critical correspondence of two school teachers at the Kinchela Home for Aboriginal boys. For further work in this field see Cole, Haskins, Paisley (under review).

12. Cootamundra Herald 1967: 1.

13. Name withheld, interview by author 1998: tape 2; Jopson, Sydney Morning Herald Features, May 19 1998: 13; Hankins 1982; Link-up \& Wilson 1997.

14. Cootamundra Herald, 22 March 1967: 1.

15. Hankins 1982: 4.5.5.

16. Hankins 1982: 4.4.1-4.4.8. 
Hiscocks, in a state of advanced senile dementia, resided. 'She lies there now looking very undignified' recalled the ex-ward of the state with some relief. ${ }^{18}$

Ella Hiscocks was born in Pilliga, north-west NSW, in 1901, and began her career at the age of 21 as the teacher in charge of the segregated school at the Pilliga Aboriginal Reserve. She lived alone in town and rode out on a bicycle to the Aboriginal reserve each day. Her work at Pilliga as a young, unmarried woman gave her a lasting impression of conditions experienced on the Aborigines Protection Board reserves during the 1920s. Her memories of the people she met and worked with at that time recall the impoverishment and ill-health experienced by many people resident on Board reserves and stations. She remembered that many of the Aboriginal people at the reserve were 'half-starved'. These first-hand impressions of conditions on Aboriginal reserves contributed in future years to her ambivalent relationship with the administration during the course of her career with the Board.

From the Pilliga reserve school, Hiscocks was again put in charge of an Aboriginal school, near Lismore, NSW. She married soon after and her husband, a farmer's son with little prior involvement with Aboriginal people and no formal training in book-keeping, or indeed anything, became manager of an Aboriginal station south of Quirindi, NSW. ${ }^{19}$ The employment of men like Hiscocks' husband reflected the idea held by the Aborigines Protection and Welfare Boards that all white people apparently possessed racialised skills for living which they could pass on to Aboriginal people. At the same time as her husband became manager, Ella Hiscocks became the Matron of the Aboriginal station, a position open to her exclusively because of her status as wife of the manager. From Quirindi, the Board moved the husband and wife team to Cumeragunja where they stayed for three years. After the premature death of her husband Hiscocks was forced to return to work as a teacher at the Aboriginal school in Lismore. Over the next few years she taught at Aboriginal segregated schools in Lismore, Tuncester, Yass, and Coraki. ${ }^{20}$ It was in 1945 that Alfred Lipscombe, Chairman of the Aborigines Welfare Board, asked Hiscocks to fill in at the Cootamundra Girls' Home for an initial three months. ${ }^{21}$

\section{Working for the Board}

In an interview recorded by Peter Read after her retirement, Ella Hiscocks stressed her disagreements and frustrations with the Sydney-based Aborigines Welfare Board and the miserable economic conditions she worked under in the 1940s through to the $1960 \mathrm{~s}^{22}$ The long hours she worked, her heavy workload, the isolated geographic location of the Home, and the slow bureaucratic procedures associated with the centralised Welfare Board were the focus of her recollections in the early 1980s of her working life. ${ }^{23}$ At Cootamundra, Hiscocks was responsible for an average of 40 girls at any one time, ranging in age from as young as a few months to 16 years old ${ }^{24}$ The Home itself,

17. Name withheld, interview by author 1998: 2 .

18. Name withheld, interview by author 1998: 2 .

19. Aborigines Welfare Board Station Reports and Returns,(AWB SR \& R) 1947: 4/10747.4; Read 1980.

20. State School Records SR 10/6626, 110/7912, 10/8262.2, 10/5528.

21. Read 1980; AWBM 16 February 1945: 4/8544.

22. Read 1980.

23. Read 1980 
in the old town hospital, engendered well-remembered feelings of isolation. ${ }^{25}$ The schoolroom where Hiscocks taught each day had been the isolation ward of the hospital and she remembered with dismay: 'it was terrible ... it was a terrible job to try and work it on your own' ${ }^{26}$ Aboriginal women incarcerated in the institution as young girls also recall the associations there between the isolation of the old hospital, sickness and death. ${ }^{27}$ One of the most feared punishments was being locked alone in what was believed to have been the hospital morgue. ${ }^{28}$ Several woman recall being traumatised as girls by long hours spent locked in that section of the building as punishment by Hiscocks and other staff members. ${ }^{29}$

As well as the many tasks required in the day to day running of the institution, Hiscocks remembered her broader role in the maintenance of each girl's 'moral welfare' which, she said, required vigilance and a ceaseless work roster. ${ }^{30}$ She remembered herself as alone in her special responsibilities, stressing that while all the other staff would only work their set hours she was on call 'night and day' ${ }^{31}$ In her descriptions of the exhausting and ceaseless nature of her work, Hiscocks presents herself as a victim of the Board's limited budget and their insistence on time-consuming bureaucratic processes. She remembered in particular the way the bureaucratic processes of the Board interacted with the mainstream, 'white' welfare administration to frustrate her efforts to improve life for the Aboriginal girls at the Home. The supply of both food and clothing at the Girls' Home came from mainstream state welfare agencies. ${ }^{32}$ Food was ordered each week from a central government store, and Hiscocks had to submit exact quotes each week for each individual. ${ }^{33}$ Having to order each item and wait for delivery from a central government store over-complicated the process of buying food, a process which could, if Matron Hiscocks had been entrusted by the Board with her own account, have been bought more simply in the nearby town of Cootamundra. Clothing for the Home was supplied by the Prisons Department. As well as being of poor quality it was often inappropriate for the young girls living at the Cootamundra institution. Shoes, for example, were frequently too big, and Hiscocks recalls that on more than one occasion they 'didn't match up'. ${ }^{34}$ Hiscocks remembers being hamstrung by a central bureaucracy even in organising sport and recreation for the girls:

AWB SR\&R, Cootamundra: 4/10745.2, see also Link-Up \& Wilson 1997; Hankins 1982.

Read 1980.

Read 1980.

27. Name withheld, interview with author tape 2 1998: 2; Jopson SMH Features, May 19 1998: 13; Hankins 1982; Link-up \& Wilson 1997.

28. A small building, away from the main building was believed by some girls held at the institution to be the hospital's old morgue. Betty Ellis, interview with author, 12 May 2003; see also Hankins 1982: 4.4 .5

29. Names withheld, interview with author 1997, 1998. Betty Ellis, interview with author, 12 May 2003.

30. Read 1980.

31. Read 1980.

32. AWB SR\&R, Cootamundra, Monthly Returns 1947-1948: 4/10745.2

33. AWB SR\&R, Cootamundra, Monthly Returns, 1947-1948: 4/10745.2.

34. Read 1980. 
I'll tell you something else that made me mad ... the children liked sport and I had to send down to the Board for permission to take them anywhere ... They'd take a long time to get back ... sometimes the children would miss out because of it. ${ }^{35}$

Working in isolation from the Sydney-based Board, Hiscocks formed other allegiances outside it. The Matron recalled turning to authority figures in the local community when seeking to improve the clothing ration. She remembers prevailing, unsuccessfully, on the local town Doctor to get him to add his weight to her complaints to the Board about the poor quality of clothing issued to the girls at the Home. ${ }^{36}$ Hiscocks also received support from local branches of professional and religious women's clubs during her employment at the Home. In the article published in the Cootamundra Herald on the day of her retirement, Hiscocks praised the Cootamundra section of the Business and Professional Women's Association, the Country Women's Association and the Church of England's Women's Guild. ${ }^{37}$ Of these organisations Hiscocks said, 'I only had to mention something I wanted, and one or more organisation would respond' ${ }^{38}$ Hiscocks' support from local women's organisations indicates the awareness and endorsement of the work of the Cootamundra Girls' Home among nonAboriginal women in the rural community, a complicated historical fact that is often not remembered now.

\section{Clean and moral}

Keep your bodies and minds clean, for by doing so you will help to form a wholesome personality. Assume the dignity and carriage, which are your heritage and your right.

Mrs Irene 'Inspector' English, Aborigines Welfare Board, $1955 .^{39}$

Amidst Matron Hiscocks' complaints about the poverty of the administration and her ceaseless workload, two common themes emerge from her memories highlighting the interaction of racial and gendered discourse. Unsurprisingly, Hiscocks' memories of the Home revolve around two key and inter-related tropes: 'cleanliness' and 'morality'. Frequent references to the morality of 'cleanliness' and the possibility of Aboriginal girls 'going bad' or 'getting into trouble with the opposite sex' form a central refrain in Matron Hiscocks' memories. ${ }^{40}$ From her first impressions - that she would have 'known it by the smell of it' - Hiscocks ordered her memories of her work at the Home through the prism of cleanliness. During her time there she conducted a concerted campaign to get the Aboriginal girls from the Home accepted at the local 'white' state school. She recalled lobbying the Principal of the local High School, the local Parents and Citizens group and the Department of Education's school inspector until she was successful in convincing the school to take the fifth and sixth form girls, and eventually girls of all ages in $1950 .{ }^{41}$ One of her most persistent and persuasive arguments for why

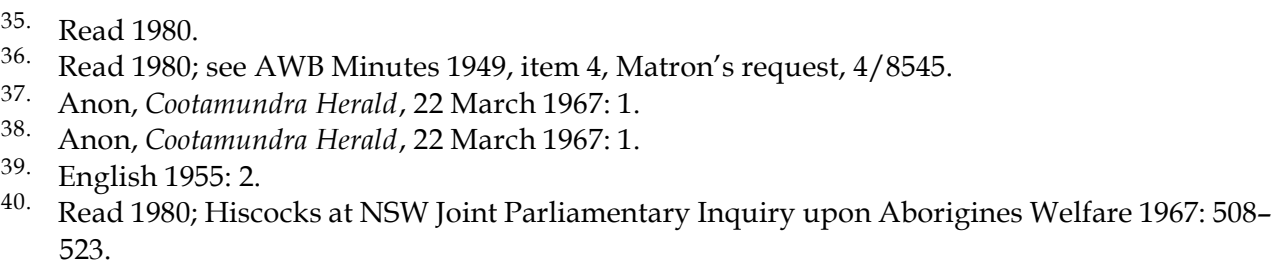


the school should take the girls from her Home, said Hiscocks, was that 'her girls' were as 'clean as local white girls'. She recalled that she finally got the girls accepted at the school after she had asked the school inspector: 'why the students can't attend the local school? They're cleaner than a lot of the white girls' ${ }^{42}$ (emphasis added).

In framing her argument to the school inspector in these terms, Hiscocks was engaging in what anthropologist Mary Douglas describes as a 'dialogue of claims and counter-claims to status' in which ideas about cleanliness, dirt and pollution are crucial. ${ }^{43}$ Wherever ideas of dirt are prominent, argues Douglas, their analysis discloses a play upon 'profound themes': reflection on dirt involves, amongst other things, reflection on the relation of 'order to disorder ... and form to formlessness'. ${ }^{44}$ In Douglas' well-known summation, dirt is 'matter out of place'. ${ }^{45}$ Such a formulation implies two conditions: a set of ordered relations and a contravention of that order:

Dirt then, is never a unique, isolated event. Where there is dirt there is a system.

Dirt is the by-product of a systematic ordering and classification of matter, in so far as ordering involves rejecting inappropriate elements. ${ }^{46}$

As an agent of the state, working at the 'boundary line' between black and white children, Matron Hiscocks reflected a wider cultural system of classification. Her constant fight against dust and dirt represented for Hiscocks an ideological struggle that is inseparable, in her account, from her real struggle against the deprivation and endless work she was required to do in the Home. The Matron strove hard to participate in the constant cleaning and constant re-ordering of the identities of the wards of the state, who had been entrusted to her surveillance and supervision. In chasing dirt, in constantly seeking to tidy, the Matron was not simply governed by an anxiety to purify, but was attempting to positively re-order her environment - and the girl's identity and seeking to make both conform to an idealised notion of white female domesticity, an ideal promoted by the government and its agencies as the key to the 'successful assimilation' of Aboriginal people.

The Matron's memories and associations with cleanliness and dirt are revealing of the system or order of beliefs that structured the processes at the core of the assimilationist policies and practices enacted haphazardly, but with brutal force, by the Aborigines Welfare Board. ${ }^{47}$ The Matron's exhausting and futile efforts to keep the young Aboriginal girls at Cootamundra clean and free from dirt coincided with a bureaucratic system that identified black as dirty and in need of expunging and assimilating into a 'clean' white culture and identity. The Matron's particular and individualised role in the production and demarcation of boundaries between white and black, clean and dirty, thus coincided both with a broader assimilationist project and with restrictive and limiting ideas about white femininity.

41. Read 1980; AWBM, 13 April 1948: 4/8545; AWBM, 25 April 1949: 4/8545. In later years the school began taking girls of all ages from the institution.

42. Read 1980

43. Douglas 2002: 3.

Douglas 2002: 44.

Douglas 2002: 3.

Douglas 2002: 35 .

47. See Goodall 1995: 75-101, also Bartlett 1999: 10-37. For a particularly powerful and disturbing account of the impact of such policy see Edwards 1982: 4-8. 
Cleaning was women's work and in the context of the racialised discourse about the 'deprivation' and 'filth' of Aboriginality, Matron Hiscocks' work was never done. Anything that increased the level of 'dirt' also increased the workload of the Matron, whose job it was to 'clean' the Aboriginal girls to make them acceptable to white society. She remembered angrily that the Board supplied the Home with an old covered truck, 'like they used in the war' to get the girls to school each morning. ${ }^{48}$ Every morning on the way to school the dust thrown up on the children in the back of the open truck threatened Matron's tireless efforts to keep the children clean. When Peter Read interviewed her in 1980 he suggested to her that the girls must have been cold on the back of the open truck in winter. Matron Hiscocks was angry at this line of questioning and cut short his comment, saying, 'you know what the dust is like. By the time they got down to school their navy blue tunics would be grey'. ${ }^{49}$ Questioning her about the girl's experience of the cold seemed to disturb Matron Hiscocks' reminiscences of her own hard work and of her victimisation at the hands of the inefficient Aborigines Welfare Board. Her response to Read's question by alluding to the dust shows something of the way that, in Douglas' words, 'uncleanness or dirt is that which must not be included if a pattern is to be maintained' ${ }^{50}$ The 'pattern' in this instance was Hiscocks' belief that the 'polluting' factors which interrupted the Board's - and her own - best efforts to uplift the girls was the random element of dust or dirt. Yet, at the same time as Matron was working ceaselessly to 'civilise' and whiten the girls in her care, stroking their Aboriginal noses to turn them straight, working endlessly to ensure their cleanliness, these same girls were driven into town on the open back of the truck, like cattle, like 'blacks'.

Direct criticism of Board's members or its policy was not a part of the Matron's discourse. The focus of her complaints about the administration was directed at a generalised sense of 'over-work', or random dust. Hiscocks fondly remembered some of the men working for the Board during the 22 years she worked as Matron of the Cootamundra Home. Inspector Donaldson, loathed and feared among Aboriginal people throughout NSW for his tactics of child abduction, ${ }^{51}$ was, in her estimation, 'a fine old gentleman ... [who] did very good work amongst them'. (Hiscocks' husband had applied for the job of Inspector held by Donaldson, but had died before he could begin). ${ }^{52}$ Hiscocks' loyalty and evident fondness of the men working for the Board sits in an ambivalent relationship to the anger and frustration evident in her memories of the ceaseless workload, the slowness of the central bureaucracy to support her basic needs such as food and clothing, her lack of financial autonomy, and her persistent sense of isolation from the administration.

\section{Throwing her to the dogs}

As with her constant battle against 'dirt', the pressures of Hiscocks' work frustrated her efforts to maintain strict supervision over the 'moral welfare' and sexual experiences of her young charges. As the only employee at the Home who could drive, one of her

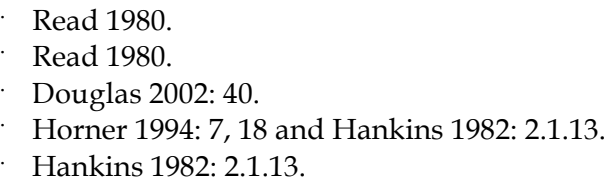


duties was to travel out to country stations to meet prospective employers of young domestic service 'apprentices' when they reached the age of fifteen. ${ }^{53}$ Due to work pressures at the Home, she remembered that she had to abandon the practice of interviewing prospective employers before taking the young 'apprentice' to work for them: 'In the end I'd take the girl out with me and if everything was in order I'd leave her there' ${ }^{54}$ She remembered only one occasion where she decided against leaving the young woman. Asked if she ever got the feeling the young apprentices were overworked or abused in some way she replied flatly, 'No'. Ex-apprentices sent out to work as domestic servants recall that often the Matron was the only contact they had with someone outside the household they worked in whom they could tell of the physical and often sexual abuse they experienced in these positions. ${ }^{55}$ As with her battle against 'dirt', the pressures of Hiscocks' work within an inefficient bureaucracy frustrated the Matron in her efforts to maintain strict supervision over the sexual experiences and 'moral welfare' of her charges.

While Hiscocks' workload militated against her enforcing the high 'moral standards' she was expected to oversee, she expressed a clear interest in the role she sought to play in 'reforming the girls' and ironically saw the removal of young Aboriginal girls from sexual threat as one of the main reasons they were taken from their Aboriginal communities. ${ }^{56}$ She recalled in detail the time she was instructed to accompany a young woman to a remote Aboriginal station, where she was to be left in punishment for repeatedly running away from domestic service positions. Hiscocks remembered her own and the young woman's distress: the apprentice 'cried all night' and the Matron recalled that she 'cried too' ${ }^{57}$ By morning, Hiscocks, in a rare moment of open disobedience, decided against the Board's instructions, and refused to leave the young woman at the Aboriginal station. In explaining her actions she said: 'I couldn't have left her ... I would have felt like I was throwing her to the dogs. She was just of that age and all the boys would have been after her'. ${ }^{58}$

Ex-apprentices have since told how being returned to an Aboriginal station, although disorienting and frightening after years away, could provide a much needed source of community after the isolation and exploitation of domestic service. ${ }^{59}$ In this instance, Hiscocks sent the young woman to work as a domestic servant for a friend of hers in the country. Matron's perception of a predatory Aboriginal male sexuality on Aboriginal stations perhaps shows us something of her merged identity with the young Aboriginal children and women in her charge. It also, of course, represented a typical racist depiction of Aboriginal men. Yet Hiscocks' fears about Aboriginal stations and reserves, expressed in sexual terms, are contradicted by her own experience of working on these stations before she was married:

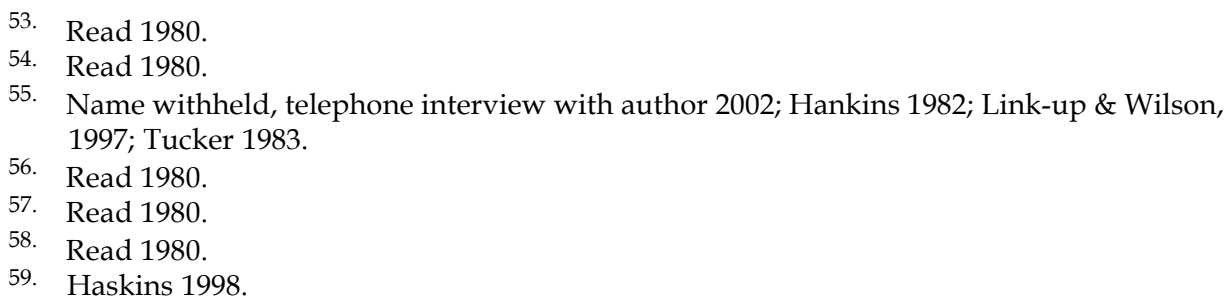


Very seldom ... you'd come across a girl who'd get in trouble on the settlement and have an infant or anything like that you know. The law amongst them was very strict on that count. ${ }^{60}$

Hiscocks appeared to have had no understanding of the gendered dimension of the Government's child removal policy or of the long-term cultural and social purpose furthered by the Board in removing girls from their communities. After 21 years at the Cootamundra Girls Home she stated confusingly: 'I think it is very much better for the children to be left with their parents and as far as I know that has always been the board's policy to make the parents stand up and live up to it and do what they should do, and leave the child' ${ }^{61}$ While official statements of assimilation policy stated in Board minutes and reports overtly stressed the importance of training Aboriginal women to 'merge' with whites, Hiscocks, contradicting her expressed fears about Aboriginal male sexuality, remarked: 'The pity is few of them marry the dark men. You know the full bloods are very upstanding. I know only one girl who married a dark man, he was a Kinchela boy'. ${ }^{62}$

Hiscocks relied heavily on nostalgic recollections of the 'progress' made by 'her' girls and on ambivalent but largely negative attitudes towards Aboriginal mothering to justify the separation of Aboriginal girls from their mothers. For example, she could express confusion and grudging acknowledgement of the importance of their Aboriginal mothers to 'her' girls:

One girl, she became a trained nurse ... her mother came, she was a terrible woman, but she came to the Home and that girl saw her coming up the path and ran towards her and threw her arms around her and made such a fuss of her... she's still a mother you see ... but that girl, afterwards she worked with the Flying Doctors as a nurse for a long while. ${ }^{63}$

In this recollection the strong, loving emotions felt by the daughter for the 'terrible woman' were not as important as her success and individual progress as a nurse with the Flying Doctors. In another instance, reflecting on the role of the Board in removing children from Aboriginal stations, Hiscocks remarked: 'the parents were never asked. The police would come and take the girls ... it was a terrible thing to have done' ${ }^{64}$ The confusion between her own experience working in Aboriginal communities and the pervasive ideology which emphasised Aboriginal women's worthlessness as mothers, the dangers of 'moral degradation', and predatory nature of Aboriginal male sexuality form a contradictory mix in the Matron's memories. Describing her time as a teacher on Aboriginal reserves, she remarked:

[T]hat's one thing with a[n Aboriginal] settlement, you never saw any of them being thrashed. The only unkindness was there was no food and that wasn't their fault. There was no food ... a lot of malnutrition. You were restricted you couldn't give the people rations except the old people unless they were working on the settlement; there was no money around anywhere those days. ${ }^{65}$

\footnotetext{
60. Read 1980.

61. Hiscocks 1966: 511.

62. Read 1980.

63. Read 1980

64. Read 1980.

65. Read 1980
} 
Her lived experience of Aboriginal communities was mixed but continually contradicted by a system of belief in which Aboriginality was an inferior identity and whiteness the goal and desire. Asked again about the causes of malnutrition amongst the Aboriginal people she worked with, Hiscocks replied it was because 'they only thought of today'. So despite her own experiences of life on Aboriginal reserves, which she contrasted favourably with institutional life, she concluded ambivalently in the late 1960s:

I do not think that any institution can equal the natural home life. But these children are not getting a natural home life. Because dark people naturally live unto the day they do not look after tomorrow even, and very often they would be hungry and they would not get a natural life in that respect. I think they are very much better off in an institution than they would be in some of their home lives. ${ }^{66}$

These contradictory statements are evocative of a consciousness caught between a rationalisation for the role she played in the separation of children from their families and a different understanding of Aboriginal communities gained from her years in the field. She was part of a system which believed Aboriginality itself was an aberrant condition to be replaced with an 'assimilated' identity suitable for white society, yet at times her own emotional connection to the 'girls' in her care, and her previous experience as a single woman working on Aboriginal reserves, conflicted with her official role. Hiscocks' ambivalent memories of her time at the Home and the contemporary testimony recorded during a late 1960s government Committee reflect and enact the particular shifting intersections between 'race', 'class' and 'gender' ${ }^{67}$

\section{Ending up in bother}

Towards the end of her long career at the Cootamundra Girls Home, Hiscocks came before a Parliamentary inquiry 'upon Aborigines Welfare' that toured NSW in $1966 .{ }^{68}$ The theme of young Aboriginal women's sexuality was persistent in both the questions and answers exchanged between Hiscocks and the parliamentary representatives. Their exchange is evidence of the way that, as recent post-colonial writing has argued, sexual control is fundamental to the way racial policies are secured and colonial projects carried out. The committee sought an efficient, 'modern', and mechanistic way of dealing with what appeared to them to be a self-evident 'problem': the sexuality of single Aboriginal women. As one committee member explained the problem:

These girls are going to Sydney, finding a job and ending up in bother ... Where is this thing to be tackled? What machinery have we set up to give these girls guidance?

They asked Hiscocks to comment on what happened to the girls when they left the Cootamundra Home. Hiscocks answered that 'all the girls' ended up pregnant within a short time after leaving the Home: 'The same thing happens to the whole lot of them, they go to Sydney and in no time they are in trouble, as I told you, and the baby arrives.' When questioned if the fathers are 'white boys', Hiscocks replied: 'mostly the

Read 1980.

67. There is a rich literature on the ambivalence of memory and oral testimony. See eg Thomson et al 1994: 33- 43; Stuart 1994: 55-63. A useful Australian collection is Donaldson et al 1992.

68. The Joint Committee of the Legislative Council and Legislative Assembly upon Aborigines Welfare, Parts 1 \& 11 1967, Hiscocks' testimony. 
whites, a terrible lot of the sailors I think. They meet every boat that comes in pretty well'. In Hiscocks' explanation it was the lecherousness of men that created the circumstances under which the young women got pregnant: 'you only have to get on a train, and a few men will get in the train and they will never let up on them if you are not with them ... they are only prey for the men there ${ }^{6}{ }^{69}$ In the ensuing questions and answers, members of the Parliamentary inquiry concluded that the number of girls 'getting into bother' was 'tied up with poor intellectual ability and low reasoning ability' and that 'we have found a pattern that the coloured people are not immoral but amoral' ${ }^{70}$ Dismissing her own earlier opinion that white men were culpable for much of the 'bother' the girls got themselves in, Hiscocks reverted to a culturally-essentialist explanation of the young women's high pregnancy rates concluding that 'amongst aborigines themselves there is no courtship ... I do not think it worries them at all' ${ }^{\prime}{ }^{7}$

Stark contrasts between Hiscocks' recorded testimony before the government Committee in 1966 and her later interview with Read underline both the ambiguities and subjectivity of memory and reflect her conflicted and marginal position within the administration. In 1966, in front of a parliamentary Committee that would eventually recommend the end of the Aborigines Welfare Board, Hiscocks is quizzed about whether there is any 'conflict or over-control' from the Board. ${ }^{72}$ In light of her repeated complaints about bureaucratic control and inefficiency - a theme in her later interview - her unequivocal answer is surprising:

No. I have never had any worry in any shape or form all the time I have been with the board. I have always pulled with them and they have pulled with me. I have never asked for anything I could not get.

This statement reflects Matron's loyalty to the Board and also her deep dependency on it for her income and, after 21 years of service with them, for her sense of identity and meaning. Only much later, from the vantage point of 20 years and retired from the Board, could Hiscocks recall her deep frustration with the administration. The influence of the interviewer himself, as in every oral history interview, must be taken into account here, and the changed political context in which his questions were posed must equally be relevant. But Hiscocks' ambiguous memories also reflect her position in the administration, her long experience with Aboriginal people, and her limited sympathy with them, as a teacher and a single woman, as a station matron and a married woman and later as a widow. As the longest-serving Matron at Cootamundra Home her experiences were in constant conflict with her role as a functionary of the Board and this is reflected in her later interview.

Matron Hiscocks is a contradictory and complex character and her conflicting testimony is revealing, I think, of the impossibility of seeking to act humanely while supporting the systematic denial of Aboriginal culture and identity that is inherent in the policy of assimilation. Hiscocks embodied some of the most abiding contradictions in the 'colonial' administration's economy of white female labour. That is, she was protected by racial privilege but not by economic security. She was 'inferior' in the gender

69. The Joint Committee 1967, Hiscocks' testimony: 512-13.

70. The Joint Committee 1967, Hiscocks' testimony: 512.

71. The Joint Committee 1967, Hiscocks' testimony: 512.

72. The Joint Committee 1967, Hiscocks' testimony: 511. 
and class hierarchy of mainstream white culture but seen as 'superior' in the racial hierarchy. She lodged among 'black girls', on their way to a life of under-paid and often unpaid domestic service ${ }^{73}$, but she was not one of them. The isolation experienced by the Matron, the slowness with which central office responded to her requests, and the indignities of being made to constantly rely on outside state agencies make her in many ways an abject figure. Marginal, in terms of power to control her working life and conditions, but necessary to the colonial state, Hiscocks is a representative of the boundaries and limits of women's roles in the domestication of colonisation. ${ }^{74}$ As a final, ironic and complex addendum, the Aboriginal 'daughter' she adopted at the Home as a baby, and towards whom she had shown some of her most human affection, became as an adult one of the first courageous Aboriginal spokespeople to expose and damn the systematic policy of Aboriginal child removal and the use of institutions such as Cootamundra in the state-sanctioned destruction of Aboriginal families and wider communities.

\section{References}

\section{Primary sources}

Aborigines Welfare Board Minutes 1938-1969, 5 October 1938 - 29 April 1969, (4/8544--48; microfilm copy AO Reels 2792-2794, restricted), Globe Street Archives Office, Sydney, NSW.

Aborigines Welfare Board Station Reports and Returns, 1942-1948, Cootamundra Monthly Returns, 4/10745.2 4/10743.1 - 4/10749.2, Globe Street Archives Office, Sydney, NSW.

Anon 1967, 'Final episode in outstanding woman's story', Cootamundra Herald, Wednesday 22 March: 1.

NSW Joint Parliamentary Inquiry upon Aborigines Welfare 1965-67, 4th session of 41st Parliament, NSW Joint volumes of Papers, vol 5, NQ 3228.94401 8, NSW State Reference Library, Sydney.

Read, Peter 1980, Recorded Interview with Ella Hiscocks lodged at Australian Institute of Aboriginal \& Torres Strait Islander Studies (AIATSIS), Listening Room, Canberra.

State School Records 1948-49, SR 10/6626, 110/7912, 10/8262.2, 10/5528, Globe Street Archives Office, Sydney, NSW.

The Joint Committee of the Legislative Council and Legislative Assembly upon Aborigines Welfare, Parts 1 \& 11 1967, Matron Ella Hiscocks testimony in ‘Evidence and

73. The wages paid to apprenticed Aboriginal domestics were set by the Board, with the majority of the weekly wage paid into a trust account and only a small amount of 'pocket money' given to the apprentice. The set wage was small relative to standard wages for domestic servants. Most girls considered the pocket money they received too small to buy anything decent. Many girls never received any pocket money from their employers. Evidence suggests that large numbers of Aboriginal apprentices, whose wages were paid into Protection and Welfare Board trust accounts never received those wages upon the completion of their apprenticeships. See Walden 1995: 1-7; Tucker 1983: 116; Horner 1983: 7-17; Shea 1983.

74. On similarities with the role of the white governess in South African colonies, see McClintock 1995: 258-300. 
Report and Minutes of the Proceedings', NSW Parliamentary Papers (5), 4th Session, 41st Parliament: 508-523.

Tapes recorded by author, May 1997- 2003, held by author.

\section{Secondary sources}

Bartlett, Francesca 1999, 'Clean white girls: assimilation and women's work', Hecate 25(1): 10-37.

Callaway, Helen 1987, Gender, culture and empire: European women in colonial Nigeria, University of Illinois Press, Illinois.

Chaudhuri, Nuper and Margaret Strobel, (eds) 1992, Western women and imperialism: complicity and resistance, Indiana University Press, Bloomington.

Cole, Anna 2000, 'The glorified flower: race, gender and assimilation in Australia, 19371977', PhD thesis, University of Technology, Sydney.

Cole, Anna, Victoria Haskins, Fiona Paisley (under review, Aboriginal Studies Press, Canberra), Uncommon ground: white women and Aboriginal history, Aboriginal Studies Press, Canberra.

Donaldson, I, P Read and J Walter (eds) 1992, Shaping lives: reflections on biographies, Humanities Research Centre, ANU, Canberra.

Douglas, Mary 2002 [1966], Purity and danger: an analysis of the concepts of pollution and taboo, Routledge Classics, London.

Edwards, Coral 1982, 'Is the ward clean...?', All that dirt: Aborigines 1938: an Australia 1938 monograph, Bill Gammage and Andrew Markus (eds), History Project Inc, Canberra: 4-8.

English, Irene 1955, 'Message to our people', Dawn: a magazine for the Aboriginal people of NSW, Government Printer, NSW, March 1955: 2.

Goodall, Heather 1995, 'Assimilation begins at home: the state and Aboriginal women's work as mothers in NSW, 1900-1960', Labour History 69(Special Edition): 75-101.

Hankins, Carla 1982, “"The missing links”: cultural genocide through the abduction of female Aboriginal children from their families and their training for domestic service, 1883-1969', BA(Hons) thesis, University of NSW.

Haskins, Victoria 1998, “"My one bright spot": a personal insight into relationships between white women and Aboriginal women under the NSW Aborigines Protection Boards Apprenticeship Policy, 1920-1942', PhD thesis, University of Sydney.

Horner, Jack 1983, 'Pearl Gibbs: a biographical tribute', Aboriginal History, 17(1): 7-17.

1994 [1974], Bill Ferguson: fighter for Aboriginal freedom: a biography, J Horner, Canberra.

Human Rights and Equal Opportunities Commission 1997, Bringing them home: report of the National Inquiry into the separation of Aboriginal and Torres Strait Islander children from their families, Government Printer, Sydney.

Jopson, Debra 1998, 'Home ties', Sydney Morning Herald Features, May 19: 13.

Knapman, Claudia 1986, White women in Fiji, 1835-193: the ruin of empire?, Allen \& Unwin, London.

Link-up (NSW) \& Tikka Jan Wilson 1997, In the best interest of the child? Stolen children: Aboriginal pain, white shame, Aboriginal History Inc Monograph 4, Canberra. 
Mager, Anne Kelk 1999, Gender and the making of a South African bantustan, Heinemann, Oxford.

McClintock, Anne 1995, Imperial leather: race, gender and sexuality in the colonial conquest, Routledge, New York.

Shea, Violet 1983, in Lousy Little Sixpence, Alec Morgan (Director), Sixpence Productions, ACT.

Stoler, Ann 1995, Race and the education of desire: Foucault's history of sexuality and the colonial order of things, Duke University Press, London.

Stuart, Mary 1994, 'You're a big girl now: subjectivities, feminism and oral history', Oral History, Autumn, 25th Anniversary issue: 55-63.

Thomson, Alistair, Michael Frisch and Paula Hamilton 1994, 'The memory and history debates: some international perspectives', Oral History, Autumn, 25th Anniversary issue: 33-43.

Tucker, Margaret 1983 [2nd edition], If everyone cared: autobiography of Margaret Tucker $M B E$, Grosvenor, London.

Walden, Inara 1995, '"To send her to service": Aboriginal domestic servants', Indigenous Law Bulletin On Line Issues, 3(76):1-7.

Ware, Vron 1992, Beyond the pale: white women, racism and history, Verso, London. 